\title{
PENERAPAN VIDEO MODELING DAN VIDEO- FEEDBACK TRAINING DALAM MATA KULIAH RENANG GAYA PUNGGUNG
}

\author{
Tri Winarti Rahayu ${ }^{1}$, Agus Margono ${ }^{2}$, Budhi Satyawan ${ }^{3}$ \\ ${ }^{123}$ Universitas Sebelas Maret Surakarta \\ triwien_rhy@yahoo.co.id
}

\begin{abstract}
Abstrak
Penelitian ini bertujuan untuk meningkatkan hasil belajar renang gaya punggung pada mahasiswa penjaskesrek dengan menggunakan media video modeling dan pemberian feedback training.

Metode penelitian ini, menggunakan metode penelitian tindakan kelas. Prosedur penelitian berbentuk siklus. Setiap siklus terdiri dari empat tahap meliputi: perencanaan, pelaksanaan tindakan, observasi dan refleksi. Teknik pengumpalan data melalui lembar observasi dan tes. Pengumpulan data ini menggunakan instrumen berupa lembar observasi penelitian sedangkan untuk mengetahui kualitas hasil belajar mahasiswa digunakan tes praktek dan teori tes renang gaya punggug.

Peneltian ini dilakukan sebanyak dua siklus. Masing-masing siklus terdiri dari empat pertemuan. Hasil penelitian menunjukan bahwa penggunaan video modeling dan pemberian video feedback training dapat meningkatkan hasil belajar renang gaya punggung pada mahasiswa penjaskesrek.
\end{abstract}

Kata kunci : video modeling, feedback training, renang gaya punggung

\section{PENDAHULUAN}

Renang merupakan matakuliah wajib di Fakultas Keolahragaan UNS baik pada program studi Penkepor atau Penjaskesrek. Pada prodi Penjaskesrek mata kuliah ini ditempuh mahasiswa dalam dua semester, yaitu mata kuliah Renang Dasar pada semester genap dan mata kuliah Renang Lanjut pada semester gasal. Pada mata kuliah Renang Dasar, mahasiswa dituntut mempunyai dua kompetensi gaya berenang, yaitu renang gaya crawl (bebas) dan renang gaya dada. Sedangkan pada mata kuliah Renang Lanjut mahasiswa dituntut mempunyai kompentensi renang gaya punggung dan gaya kupu-kupu. Untuk mencapai kompetensi dalam mata kuliah renang tidaklah mudah karena renang merupakan salah satu matakuliah yang mempunyai tingkat kesulitan cukup tinggi dan banyak ditakuti oleh mahasiswa, baik pada mata kuliah Renang Dasar maupun mata kuliah pada Renang Lanjut. Pada matakuliah Renang Lanjut mempunyai kesulitan yang lebih komplek dibandingkan dengan mata kuliah Renang Dasar, hal ini disebabkan karena gaya berenang yang harus di kuasai pada mata kuliah Renang Lanjut, gerakannya lebih sulit dan kompleks. Pada mata kuliah Renang Lanjut ini mahasiswa dituntut untuk menguasai renang gaya punggung dan renang gaya kupu-kupu. Memfokus pada renang gaya punggung banyak mahasiswa yang 
mengalami kesulitan dan tidak punya keberanian serta ketidaknyamanan dalam melakukan gerakanya karena mereka harus berenang dengan posisi telentang atau bagian punggung berada di permukaan air, hal ini sangat berbeda dengan ketiga gaya renang yang lainya, dimana posisi berenang nya dalam posisi telengkup. Agar dapat membiasakan posisi telentang dalam renang gaya punggung di perlukan metode yang tepat, termasuk di dalamnya penggunaan media yang sesuai dalam proses belajar mengajarnya agar mahasiswa dapat memahami materi yang disampaikan sehingga dapat mengusai renang gaya punggung tersebut.

Observasi di lapangan menunjukan hasil belajar pada mata kuliah renang gaya punggung mahasiswa penjaskesrek kurang optimal. Mereka merasa kesulitan untuk mendapatkan nilai 70, Hal ini disebabkan oleh beberapa faktor, diantaranya faktor kesungguhan dan keseriusan dalam mengikuti mata kuliah renang, keberanian untuk mencoba, dan kesulitan mahasiswa memahami materi sehingga berdampak pada kesulitan mempraktekan gerakan. Berdasarkan permasalahan tersebut, tim teaching berusaha untuk mencari solusi yang tepat. Salahsatu faktor yang akan dijadikan sebagai solusi adalah pemilihan media pembelajaran dan pemanfaatan feedback melalui media audio visual. Ada beberapa pilihan media pembelajaran yang dapat digunakan untuk menyampaikan materi pembelaajran. Memilih atau menentukan media pembelajaran harus yang benar-benar sesuai dengan kondisi siswa dan materi pelajaran yang akan disampaikan,karena pemilihan media pembelajaran yang tepat akan menentukan tingkat keberhasilan siswa dalam menguasai suatu keterampilan tertentu.

Renang gaya punggung merupakan gaya renang yang berbeda dibandingkan dengan renang gaya lainya. Karena pada saat melakukan gaya ini, tubuh menghadap keatas dan mengambang diatas permukaan air. Pada renang gaya ini, perenang juga tidak dapat melihat bagian depan yang akan dituju. Hal ini merupakan kendala yang dihadapi bagi pemula untuk menguasai renang gaya punggung. Meskipun sulit, renang gaya punggung mememiliki keuntungan atau kemudahan dalam pengambilan napas karena pada saat melakukan teknik pengambilan napas perenang. Prinsip dan mekanis renang gaya punggung sama dengan prinsip dan mekanis yang berlaku pada gaya renang lainnya. Teknik dasar renang gaya punggung meliputi: posisi badan; gerakan tungkai; gerakan lengan; teknik pengambilan napas; dan koordinsi gerakan keseluruhan.

1. Posisi badan renang gaya punggung telentang mendatar dibawah permukaan air kecuali pada bagian kepala atau muka yang tetap berada di atas permukaan air sebatas telinga, sehingga muka selalu berada di atas permukaan air. Letak punggung hampir rata, sedangkan letak kedua kaki, panggul sedikit lebih rendah dibandingkan dengan kepala dan bahu, pandangan ke atas. Bagi pemula, akan cukup sulit untuk membuat posisi terlentang pada reanang gaya punggung karena takut tenggelam dengan posisi tersebut. Meskipun sebenarnya ketakutan seperti itu tidak perlu terjadi jika perenang dapat melakukan posisi 
telentang pada renang gaya punngung dengan teknik yang benar dan rasa percaya diri yang tinggi.

2. Gerakan tungkai pada renang gaya punggung sama dengan gerakan tungkai pada renang gaya bebas, yaitu tungkai bergerak naik turun pada bidang horizontal, yang membedakan adalah pada gaya punggung gerakan tungkai dilakukan dalam posisi terlentang sedangkan padarenang gaya crawl gerakannya dilakukan pada posisi tengkurap. Gerakan tungkai dimulai dari pangkal paha, lutut sedikit dibengkokkan dan berakhir dengan kibasan ujung kaki. Gerakannya adalah naik turun pada bidang horizontal. Gerakannya dilakukan secara rilex dan tidak kaku.

3. Gerakan tangan pada gaya punggung tahapannya sama seperti gaya crawl, yaitu yang meliputi gerakan menarik, gerakan mendorong, dan gerakan kembali. Gerakan menarik gerakan ini dimulai dengan posisi lengan lurus di belakang kepala, jari-jari kelingking di bawah. Permulaan akan mengadakan gerakan menarik telapak tangan berada di bawah permukaan air $\pm 25 \mathrm{~cm}$. Gerakan dimulai dengan sikut agak dibengkokkan kemudian menarik dengan kuat sampai lengan mendekati badan. Gerakan menarik berakhir saat lengan atas menyentuh badan, dan kemudian dilanjutkan dengan gerakan mendorong. Sedangkan gerakan mendorong; gerakan ini dimulai setelah lengan atas menyentuh atau mendekat pada badan selanjutnya dengan cepat lengan bawah mendorong sampai telapak tangan mendekati paha. Umumnya gerakan menarik lebih besar kekuatannya dibanding gerakan mendorong. Karena gerakan mendorong dilakukan mendekati berakhirnya gerakan tangan. Pada akhir gerakan mendorong akan dimulai dengan gerakan kembali (recovery).- Gerakan kembali; dilakukan setelah tangan menyentuh badan, terjadilah gerakan kembali.

4. Pengambilan napas pada gaya punggung dilakukan melalui mulut dan hidung, pada saat kedua lengan berada di dalam air, yaitu pada saat kedua lengan dalam posisi mendatar, saat lengan yang satu masuk dan lengan lainnya akan keluar.

5. Latihan koordinasi renang gaya punggung adalah latihan dari semua unsure gerakan yang ada pada gaya punggung, yaitu mulai dari gerakan meluncur, kemudian dilanjutkan dengan gerakan kaki, lengan dan pernapasan, sehingga gaya punggung dapat dilakukan dengan benar. Utuk mendapatkan tenaga maksimal, perlu keseimbangan seluruh tubuh. Hal mi dapat dihasilkan atas keserasian dan ketepatan gerak antara lengan dan kaki.

Untuk dapat menguasai renang gaya punggung diperlukan perangkat pembelajaran yang menunjang, salah satunya adalah media pembelajaran yang sesuai, dengan materi yang akan di berikan. Pemilihan media pembelajaran yang sesuai dengan materi pembelajaran yang akan diberikan akan mempermudah mahasiswa untuk memahami dan menguasai keterampilan gerak tertentu. Salah satu media pembelajaran yang dapat di jadikan sebagai solusi dalam mempelajari renang gaya punggung adalah dengan menggunakan video modelling. Video modeling adalah suatu metode belajar, dimana atau siswa belajar dengan melihat atau mengamati model dalam video yang memperagakan suatu target keterampilan 
tertentu. Model yang terlibat bisa teman kelompok dari anak tersebut, saudaranya, orang dewasa lain atau orang lain yang lebih dari satu atau anak itu sendiri sebagai model. Video modeling adalah suatu bentuk rekaman video tentang seseorang yang sedang melakukan suatu kegiatan atau perilaku tertentu.

Video modeling merupakan bagian dari media pembelajaran. Video modeling masuk dalam media audio visual. Video modeling adalah bentuk pembelajaran observasional di mana perilaku yang diinginkan dipelajari dengan menonton demonstrasi video dan kemudian meniru perilaku model. Video modeling dapat digunakan untuk membantu mempelajari dan memahami materi yang disamapaikan olaeh guru.,Teknik yang melibatkan demonstrasi perilaku yang di inginkan melalui presentasi video di sebut dengan video modeling. Intervensi model melalui presentasi video akan melibatkan individu akan menonton yang ditayangkan lewat video kemudian meniru perilaku model. Anak-anak akan mendapatkan keterampilan yang luas dengan mengamati orang lain melakukan. Bukan hanya melalui pengalaman pribadi anak sendiri. Dalam video modeling, model yang digunakan bisa orang dewasa, teman sebaya, kelompok, saudara kandung, diri sendiri sebagai model (video self modeling/VSM) maupun kombinasi atau campuran dari berbagai model. (Kathleen, 2007).

Selain penggunaan media pembelajaran yang tepat, dalam proses pembelajaran juga di perlukan video feed-back training atau pemberian umpan balik dengan menggunakan media video. Pemberian feed-back ini bertujuan untuk pemberitahukan kepada siswa tentang keterampilan gerak yang telah di pelajari., Umpan balik yaitu guru mengobservasi siswa secara individu dan menilai bagaimana siswa melakukan aktivitas serta apa yang harus dilakukan guru untuk meningkatkan kemampuan siswa itu (Suherman 1998 )." Feed back (umpan balik) adalah pengetahuan yang diperoleh berkenaan suatu tugas, perbuatan atau respon yang diberikan (Rusli Lutan, 1988: 300). Umpan balik dapat dilakukan dalam banyak bentuk dan dari berbagai sumber. Siswa menerima umpan balik dari guru, teman sekelas, dan bahkan diri mereka sendiri.

\section{METODE}

Penelitian dilakukan pada mahasiswa Pogram Studi Penjaskesrek FKOR Universitas Sebelas Maret Surakarta yang mengambil mata kuliah renang II di semester ganjil. Sumber data di kumpulkan dari (1) nara sumber yaitu dosen dan mahasiswa yang terlibat dalam mata kuliah renang II (2) hasil observasi peneliti pada pembelajaran renang II dengan materi renang gaya punggung semester ganjil 2018/2019 pada Program Sudi Penjaskesrek FKOR Universitas Sebelas Maret Surakarta. Teknik pengumpulan data dengan menggunakan lembar observasi penelitian, lembar penilaian proses dan hasil belajar mahasiswa. Analisis data yang digunakan adalah analisis kualitatif yang terdiri dari (1) mereduksi data, (2) menyajikan data, (4) menarik kesimpulan dan verifikasi. Jenis penelitian yang digunakan adalah Penelitian Tindakan Kelas (PTK) dengan Pendekatan pendekatan kualitatif. Desain penelitian yang 
digunakan adalah model Kemmis \& Mc Taggart (1988). Setiap siklus terdiri dari planning (rencana), action (tindakan), observation (pengamatan), dan reflection (refleksi).

\section{HASIL DAN PEMBAHASAN}

Penelitian ini terdiri dari dua siklus. Setiap siklusnya terdiri dari 4 pertemuan.

\section{Siklus pertama terdiri dari empat pertemuan \\ Perencanaan}

1) Peneliti dan kolaborator merancang rencana pembelajaran renang gaya punggung. Pembelajaran renang gaya punggung diberikan secara bertahap. Tahapan gerak renang gaya punggung terdiri dari gerakan (1) tungkai, (2) lengan, (3) teknik pengambilan napas dan (4) gerak koordinasi. Materi dan feedback di sampaikan dengan menggunakan media video.

2) Membuat lembar observasi penelitian dan lembar observasi penilain hasil belajar mahasiswa

\section{Tindakan}

1) Peneliti (dosen) mengumpulkan mahasiswa dan memberikan penjelasan bagaimana melakukan gerakan di setiap tahapan renang pada renang gaya punggung melalui media video. (video modeling) Tahapan gerak meliputi ; gerakan tungkai, lengan, teknik pengambilan napas dan gerak koordinasi. Materi gerakan ini di sampaikan dengan menggunakan media video dan mahasiswa di minta untuk mengamati dan mencermati setiap gerakan yang ditampilkan tersebut.

2) Mahasiswa di bagi menjadi 5 kelompok berbanjar sesuai dengan lintasannya masingmasing. Barisan depan melakukan gerakan melewati teman sekelompoknya dalam satu barisan. Setelah mahasiswa baris pertama selesai melakukan, dilanjutkan dengan baris kedua yang melakukan, begitu seturusnya secara bergantian.

3) Ketika mahasiswa mencoba melakukan gerakan, gerakan yang mereka lakukan di rekam dengan video kemudian hasil rekaman video tersebut akan di jadikan sebagi bahan untuk memberikan feedback.

4) Dalam setiap kelompok, mahasiswa di minta saling mengoreksi gerakan yang dilakukan oleh temanya antara satu dengan yang lainnya. Kekurangan yang dilakukan oleh teman dalam satu kelompok di sampaikan untuk perbaikan gerakan yang akan dilakukan berikutnya. Koreksi yang diberikan tidak hanya secara verbal tapi juga dilakukan dengan menggunakan media video,

5) Setelah masing-masing mencoba sebanyak $10 \mathrm{kali}$, semua di minta naik untuk diberikan koreksi secara klasikal, baik secara langsung (verbal) maupun dengan media video dan kemudian mereka turun kembali ke kolam.

6) Dosen memberikan evaluasi serta memberikan pengarahan terhadap pembelajaran yang sudah dilaksanakan 


\section{Observasi}

Pada siklus pertama, mahasiswa dapat melaksanakan dan mengikuti instruksi yang di berikan oleh dosen. Mereka terlihat antusias dalam memperhatikan tayangan video pembelajaran renang gaya punggung yang di sampaikan. Kendala yang terjadi ada beberapa mahasiswa yang belum dapat focus memperhatikan tayangan video dan beberapa yang masih terlihat mengobrol sendiri, hal tersebut berdampak pada saat mereka praktek di kolam, mahasiswa yang belum dapat focus dan masih ngobrol sendiri saat penayangan video, akan mengalami kesulitan saat harus melakukan gerakan di kolam. Seain itu mahasiswa yang masih malu bertanya setelah penayangan video juga menjadi kendala sendiri saat mereka harus melakukan gerakan di kolam. Selain itu feedback yang diberikan oleh teman berupa video gerakan renang, kadang tidak jelas gerakannya karena pengaruh pengambilan yang tidak focus dan tergesa-gesa dan jarak pengambilan yang terlalu jauh.

\section{Refleksi}

Dari hasil observasi yang telah di dapatkan, solusi yang akan di gunakan adalah sebagai berikut;

1) Mahasiswa yang belum dapat focus memperhatikan tayangan video yang berdampak pada tingkat pemahaman yang masih rendah pada gerakan yang akan dilakukan di berikan solusi dengan memberikan peringatan untuk berkonsetrasi dalam memperhatikan tayangan video pembelajaran yang di berikan.. Untuk memberikan pemahaman yang cukup maka, gerakan video dilambatkan dan di fokuskan pada gerakan tertentu yang mereka perlukan sehingga di harapkan mereka dapat lebih jelas dan focus dalam memahami gerakan yang dilakukan.

2) Feedback secara individual yang dilakukan antar teman yang masih kurang jelas dalam penyampaiannya, di instruksikan untuk pengambil video jaraknya lebih dekat dengan objeknya, serta di saat mengambil video tidak di lakukan secara tergesa-gesa sehingga gambar geraknya menjadi tidak focus.

Berdasarkan kondisi awal hasil belajar renang gaya punggung adalah sebagai berikut; mahasiswa yang memperoleh nilai dibawah 70 sebanyak 56 mahasiswa. Setelah dilakukan tindakan di siklus pertama diperoleh hasil sebagai berikut; Mahasiswa yang memperoleh nilai dibawah 70 sebanyak mahasiswa 35 mahasiswa. Prosentase peningkatan hasil belajar renang gaya punggung di siklus pertama adalah sebagai berikut; mahasiswa yang mengalami peningkatan hasil belajar sama dengan atau lebih dari 5\% sebanyak 20 mahasiswa. Sedangkan mahasiswa yang mengalami peningkatan hasil belajar sama dengan atau lebih dari 10\% sebanyak 15 mahasiswa. Kelebihan dan keberhasilan yang ada di siklus pertama akan dipertahankan dan akan ditingkatkan pada siklus kedua. Sedangkan kelemahan atau kekurangan yang ada terdapat pada siklus pertama akan diminimalkan. Berdasarkan 
kelemahan yang ditemukan pada siklus pertama akan dilakukan upaya perbaikan pada pelaksanaan siklus kedua

\section{Siklus ke kedua terdiri dari empat pertemuan Perencanaan}

1) Peneliti dan kolaborator merancang rencana tahapan pembelajaran gerak pada renang gaya punggung. Rancangan di buat berdasarkan hasil observasi dan refleksi pada siklus pertama. Tahapan gerak dalam gaya punggung terdiri dari gerakan (1) tungkai, (2) lengan, (3) teknik pengambilan napas dan (4) gerak koordinasi.. Materi dan feed back di sampaikan dengan menggunakan media video

2) Membuat lembar observasi penelitian dan lembar observasi penilain hasil belajar mahasiswa

\section{Tindakan}

1) Peneliti (dosen) mengumpulkan mahasiswa dan memberikan penjelasan bagaimana melakukan gerakan di setiap tahapan renang pada renang gaya punggung melalui media video. (video modeling) . Materi gerakan ini di sampaikan dengan menggunakan media video dan mahasiswa di minta untuk mengamati dan mencermati setiap gerakan yang ditampilkan tersebut dengan lebih konsentrasi. Video Pembelajaran di putar 3 kali supaya mahasiswa dapat lebih memahami gerakan yang harus dilakukan. Setelah mengamati kemudian di beri kesempatan bertanya bagi mahasiswa yang belum memahami gerakan yang akan dilakukan. Selanjutnya mahasiswa mencoba melakukan gerakan yang telah di amati

2) Mahasiswa di bagi menjadi 5 kelompok berbanjar sesuai dengan lintasannya masingmasing. Barisan depan melakukan gerakan melewati teman sekelompoknya dalam satu barisan. Setelah mahasiswa baris pertama selesai melakukan, dilanjutkan dengan baris kedua yang melakukan, begitu seturusnya secara bergantian.

3) Ketika mahasiswa mencoba melakukan gerakan, gerakan yang mereka lakukan di rekam dengan video kemudian hasil rekaman video tersebut akan di jadikan sebagi bahan untuk memberikan feedback.

4) Dalam setiap kelompok, mahasiswa di minta saling mengoreksi gerakan yang dilakukan oleh temanya antara satu dengan yang lainnya. Kekurangan yang dilakukan oleh teman dalam satu kelompok di sampaikan untuk perbaikan gerakan yang akan dilakukan berikutnya. Koreksi yang diberikan tidak hanya secara verbal tapi juga dilakukan dengan menggunakan media video. Pengambilan video dilakukan dengan jarak yang lebih dekat dengan objek dan dilakukan secara focus.

5) Setelah masing-masing mencoba sebanyak $10 \mathrm{kali}$, semua di minta naik untuk diberikan koreksi secara klasikal, baik secara langsung (verbal) maupun dengan media video dan kemudian mereka turun kembali ke kolam. 
6) Memberikan evaluasi serta memberikan pengarahan terhadap pembelajaran yang sudah dilaksanakan

\section{Observasi}

Pada siklus kedua, mahasiswa yang dapat melaksanakan dan mengikuti instruksi yang di berikan oleh team teaching saat berada di kolam jumlahnya semakin meningkat,.Mereka terlihat antusias dalam memperhatikan tayangan video pembelajaran renang gaya punggung yang di sampaikan. Bahkan ada beberapa dari mereka yang mengikuti gerakan secara langsung saat video di tayangkan atau sebelum mereka masuk kolam.

Jumlah mahasiswa yang tidak focus, tidak memperhatikan tayangan video serta mengobrol sendiri, semakin berkurang.. Mahasiswa yang masih malu bertanya, beberapa sudah mulai berani utuk bertanya dengan meminta tayangan video untuk di lambatkan atau di ulang beberapa kali. Feedback yang diberikan oleh teman berupa video gerakan renang yang telah dilakukan, sudah dapat dapat dilakukan dengan jarak yang lebih dekat dan dengan konsentrasi penuh sehingga hasilnya dapat di jadikan feedback yang optimal anatar teman.

\section{Refleksi}

Dari hasil observasi yang telah di dapatkan, solusi yang akan di gunakan adalah sebagai berikut; Mahasiswa yang belum dapat melakukan gerakan gerakan renang gaya punggung dengan baik di minta untuk lebih focus lagi dan berkonsetrasi penuh video yang ditayangkan, kemudian diminta untuk mencatat dan menayakan setiap kesulitan yang ditemui pada saat mengamati penayangan video tersebut. Satu persatu yang belum diminta menunjukan pada bagian mana yang belum di pahami untuk di putar ulang videonya dan jika di perlukan tayangan video di perlambat untuk lebih memperoleh pemahaman yang baik.

Hasil siklus kedua adalah sebagai berikut; Hasil belajar renang gaya punggung Mahasiswa yang memperoleh nilai dibawah 70 sebanyak mahasiswa 21 mahasiswa. Prosentasi peningkatan hasil belajar renang gaya punggung di siklus kedua adalah sebagai berikut; mahasiswa yang mengalami peningkatan hasil belajar sama dengan atau lebih dari 5\% sebanyak 29 mahasiswa. Sedangkan mahasiswa yang mengalami peningkatan hasil belajar sama dengan atau lebih dari10\% sebanyak 26 mahasiswa. Jumlah mahasiswa yang tidak lulus pada matakuliah renang gaya punggung adalah sebanyak 5 mahasiswa

\section{KESIMPULAN DAN SARAN}

Dari hasil penelitian yang telah dilakukan dapat diambil kesimpulan sebagai berikut : (1) Penerapan video modelling dan video- feedback training dalam mata kuliah renang gaya punggung dapat meningkatkan kualitas proses pembelajaran pada Mata Kuliah Renang II pada Materi Renang Gaya Punggung. Peningkatan perolehan nilai pada mahasiswa adalah sebagai berikut; Jumlah mahasiswa yang mengalami peningkatan hasil belajar sama dengan atau lebih dari 5\% sebanyak 29 mahasiswa. Sedangkan jumlah mahasiswa yang mengalami 
peningkatan hasil belajar sama dengan atau lebih dari10\% sebanyak 26 mahasiswa. Implikasi dalam penelitian ini adalah (1) hasil penelitian ini dapat digunakan sebagai dasar penelitian selanjutnya dan dapat digunakan sebagai upaya bersama antara dosen dan mahasiswa untuk meningkatkan kualitas proses dan hasil pembelajaran renang; (2) hasil penelitian ini dapat diterapkan pada kegiatan belajar mengajar mata kuliah renang yaitu proses dan hasil pembelajaran mahasiswa dapat ditingkatkan melalui menggunaan video modelling dan feedback training dalam pembelajaran. Berdasarkan hasil penelitian maka dapat dikemukakan saran sebagai berikut; (1) Penerapan media pembelajaran dan feedback training yang menarik yang di sesuaikan dengan karakteristik materi pembelajaran sebagai upaya untuk meningkatkatkan konsentrasi dan pemahaman mahasiswa dalam pembelajaran. (2) Dosen dapat menerapkan menggunakan video modelling dan feedback training dalam mata kuliah renang untuk meningkatkan kualitas pembelajaran

\section{DAFTAR PUSTAKA}

American Red Ross. 2009. Swimming and Water Safety. American Red Cross swimming and water safety. 3rd ed.

Aquatics Coaching Guide. 2004. Teaching Aquatics Skills Learn to SwimProgram. Unified Sports Special Olympic (online) www.swimmingcoach.org diakses 02 Februari 2016 Dwiyogo, W. D. 2013.

Azhar Arsyad, media Pembelajaran, Jakarta: raja Grafindo Persada,2007

Bandura, A. 1965. Influences of models"reinforcement contingencies on the acquistion of imitative response. Journal of Personality and sosial Psychology, 1,589-595

Hamalik. O. 2005. Proses Balajar Mengajar. Jakarta: PT Bumi Aksara.

Hopkins, David. 1993. A Teacher's Guide to Classroom Research. Philadelpia: Open University Press.

Kemmis, Stephen and Robin Mc Taggart. 1997. The Action Research Planner. Geelong: Deakin University.

Kemmis, Stephen and Robin Mc Taggart. 1997. The Action Research Reader. Geelong: Deakin University.

Malang Haller, D. 2000.Media Pembelajaran. Wineka Media.. Belajar Renang. Pioner Jaya. Bandung

Mc Taggart, R. 1991. Action Research: A Short Modern History. Geelong Deaking University

Rayandra Asyhar. 2011. Kreatif Mengembangkan Media Pembelajaran, GP. Press, Jakarta.

Lutan, Rusli. 1988. Belajar keterampilan motoric pengantar teori dan metode. Jakarta:

Dikti,PLPTK.H. H. Emmen a , L. G. Wesseling a , R. J. Bootsma a , H. T. A. Whiting a \& P. C. W. van Wieringen. 14 November 2007. The effect of video-modelling and video-feedback on the learning of the tennis service by novices. Journal of Sports 
Sciences. Department of Psychology, Interfaculty of Human Movement Science, Vrije Universiteit, Amsterdam, The Netherlands.

James Ohene-Djan. Winkball for Schools: An Advanced Video Modelling Technology for

Learning Visual and Oral Communication skills. Goldsmiths College, University of London New Cross, London SE14 6NW 